\title{
The Importance of Internal Audit in Preserving the Company's Tangible Assets between Dominion Diamond Corporation and Bank of Montreal
}

\author{
Mohammed Ali Almanqari
}

Management Department, Accounting Program, Community College, Jazan University, KSA.

*Corresponding Author Email: malmanqari@jazanu.edu.sa

\begin{abstract}
This paper aims to examine the importance, or the role played by the aspect of internal auditing in preserving the tangible assets of a corporation. It also compares and contrasts the role played by internal auditing in preserving the tangible assets of Dominion Diamond Corporation and Bank of Montreal. In addition, it will evaluate the objectives of internal auditing and its overall importance in an organization.
\end{abstract}

Keywords: Internal Audit, Internal Auditing Objectives Tangible Assets, Preserving Tangible Assets, Dominion Diamond Corporation, Bank of Montreal.

\section{Introduction}

The functions and value of internal auditors have a gained a demand in the current market. With the demand of the organizations to streamline their activities, the internal auditors have gained a high demand in most of the companies and corporation. Internal audit is used to denote the independent, consulting practice and objective assurance that is designed to add value and to improve the operations of the corporations. The primary purpose of internal auditing is to aid the organizations in accomplishing their goals and objectives through incepting a disciplined, systematic and independent initiative [1].

The approach enables the organizations to carry on the evaluation of their risks and the process of governance. In most cases, the internal auditors are employees of particular corporations, and therefore they are not they are not tasked with the responsibility of executing the amenities of the organizations. Instead, the internal auditors provide guidance and counseling on the board of directors on how to carry out their executive responsibilities. Following the higher scope of their engagement, the internal auditors are required to possess a sound professional background and higher education qualifications. Internal auditing entails the ascertaining of compliance with procedures, policies, and entities. Since the scope of auditing within an entity is wide, auditors work in shifts by evaluating various sections. Among the sections involved in auditing include the efficiency of the operations and activities, evaluations of the compliance of the laws and regulations governing various practices, safeguarding of the assets and determination of fraud.

\section{The Objectives of Internal Auditing}

In the mining and banking corporations, the practice of internal auditing is highly valued. One of the objectives of internal auditing is to carry out the development and monitoring of the control frameworks of the corporations. The internal auditors also aim at establishing the reporting structures and formalizing of the communication processes and procedures. The internal auditors' function by evaluating the aspects of the corporation to ascertain the areas that should be improved. Another objective underlying the internal audit function is to reduce the costs incurred by the corporations 
and developing of the operational performance appraisals. Internal auditing also works towards monitoring risk management and evaluation in an organization. Ideally, the internal auditors aim at ascertaining the risks that may cause an adverse impact on the tangible assets. They, therefore, work towards developing the mitigation approaches to deal with the identified risks. The internal auditors also work towards supporting and advocating for corporate governance and development of resources that can aid in the management of information [2]. The internal auditors also have an objective of ensuring that the organization complies with the set rules and regulations.

\section{The Principles of Internal Auditing}

Both the bank of Montreal and the Dominion Diamond Corporation require that their internal auditors pose and embrace the principles of internal auditing. The principles are important in ensuring that the auditors perform their work effectively a fact that results in the protection of intangible assets. One of the principles of internal auditing is independence. The internal auditors should ensure that they demonstrate the aspect of independence in their practices. The internal auditors should ensure that they carry out their practices independently from the board of directors.

The internal auditors should demonstrate the aspect of professional care, competence and high level of competence. The internal auditors of both corporations are required to demonstrate the aspect of communicating effectively. The internal auditors should ensure that they communicate the feedback efficiently to the organization and the management regarding the strategies that should be embraced by the organizations to enhance their performance.

Another principle regarding the internal auditors of the corporation is that they should aim at the incepting positive change in the organizations. The internal auditors should have a motive and desire of incepting positive change in the corporation. Additionally, the internal auditors are required to demonstrate the aspect of continuous and quality improvement. The internal auditors should also demonstrate the principle of achieving effectiveness and efficiency of the delivery systems.
It is vital for the internal auditors to ensure that a high level of objectivity is shown when executing their processes during the auditing process.

\section{The Importance and Functions of Internal Auditors in a Corporation}

Internal auditors play instrumental roles in guiding the organizations on the directions that they should take to enhance their performance. Through assessing of the effectiveness of the systems and operations embraced by a particular organization, the internal auditors can equip the managers of the organization on the right systems and processes that should be implemented in the companies. The conduction of internal auditing takes place in a cultural and legal environment.

Despite the fact that the variation in the environments may affect the process of internal auditing, it is imperative to ascertain that the internal auditors are required to comply with the international standards that guide the professional practice of internal auditing. The internal auditor should also embrace the use of collaboration to aid in aligning the objectives and goals of the corporation to enhance organization integration. Principally, the internal auditors are tasked with the responsibility of evaluating the compliance measures and ascertain whether the organizations follow the right procedures and polices when making resolutions [3]

Internal audit also plays the role of assessing the internal control systems, managing the governance systems, management of risks, and managing of the process that are embraced by the corporations in carrying out their operations and activities. Additionally, the supervisors and the internal auditors embrace the use of the risk-based approaches in determining the respective actions and work plans.

Despite the fact that both the supervisors and the internal auditors varied mandate and responsibilities, they have the potential of ascertaining related or similar risks. The internal auditors are tasked with the responsibility of developing and incepting an informed and independent aspect of the encountered risks and how they should be curbed. Research studies have evidenced 
that internal audit plays a salient role in the success and performance of an organization [4]. Ideally, when internal auditing is carried out in an effective way, it helps in protecting the assets of the corporation and reducing the possibility of the occurrence of fraudulent activities. Ideally, this is because the internal auditors involve themselves in a thorough scrutiny of the operations and activities of the organization to ascertain whether there is a malpractice or indulgence in the fraudulent activities. Internal auditing also results in the improvement in the efficiency of the operations of an organization.

Typically, the internal auditors can address the area of weakness of the organization and explain to the management the areas that should be improved to enhance performance. Additionally, the practice of internal auditing aids in aiding the organizations to comply with the laws and regulations that are set by the statutory bodies. Basically, the internal auditors carry out the role of determining whether the organizations have complied with the statutory laws and regulations.

For this reason, the organizations make significant efforts to comply with the incepted regulations and rules. Furthermore, the aspect of internal auditing results in financial integrity and reliability. Ideally, this is because through compliance the organizations can curb the costs that might be incurred due to non-compliance. The aspect of internal auditing also results in the establishment of monitoring procedures within a corporation. Such procedures help in enhancing transparency in the corporation and detection of the fraudulent activities.

\section{The Role of Internal Auditing in Controlling the Intangible Assets of a Company}

As stated earlier, internal auditing is used to refer to the assessment practice and compliance control which is incepted by an organization to assess the internal control of the particular corporation. In most cases, internal auditing is carried out by the employees or the staff members of the specific organization. The internal auditors are required to have an understanding and knowledge of auditing and accounting. The primary objective of internal auditing is to aid in the detection of fraudulent activities, irregularities, and errors that may occur in the practice of the organization. Internal auditing works towards ensuring that the organization complies with the adopted policies and standards. Internal auditing ensures that the tangible assets of an organization are efficiently used a fact that enhances organization performance.

Through the evaluation of the internal control procedures, the internal auditors provide the recommendations that should be adopted by the corporation. Internal auditing is regarded as a vital aspect of management as it works towards enhancing the performance of the corporation. Internal auditors work towards monitoring the activities of the organization and ensuring that they are in line with the set standards and procedures [5].

The internal auditors carry out the function of controlling quality assurance, the aspects of self-interest, the objectives of a business and project management. Another factor that explains the importance of the internal auditors is their aspect of independence. The internal auditors work independently from the board of directors, and therefore the shareholders are benefited from such a practice. Internal auditing also works towards enhancing internal corporate governance. Following the financial scandals and economic crisis that overwhelm the corporations, internal auditing has been regarded as a valuable practice in a corporation.

Through internal auditing the activities and practices such as consultation of services, evaluation of compliance, management of risks, and controlling of assurance. The rise in public interest regarding the aspect of corporate governance has triggered the corporations to carry out a review and evaluation.

\section{The Dominion Diamond Corporation}

Before examining the significance of internal auditing in the protecting and preserving of the tangible assets of the Dominion Diamond Corporation of Canada, it is essential to evaluate the corporation, its tangible assets and the activities and operations of the organization. The Dominion Diamond Corporation is an organization in Canada which specializes in the mining of Diamond. 
The corporation has the ownership interest in two primary producing diamond mines. One of the mines is the Diavik mines while the other one is the Ekati Mines. The corporation is known to be the largest regarding Diamond production. The offices of the organization are located in India, Canada, England, and Belgium. Since its inception, the Ekati Diamond mine has been remarkable and is considered as a world class in the supplying of high-quality rough diamonds [6].

The mine is also remarkable since it offers unique operations and provides useful rewards to its employees. The corporation is outstanding since it maximizes its sales revenue from Ekati and Diavik mines. Since the company deals directly with the world manufacturers, it gets an opportunity of maximizing the value of its sales and profitability since it can involve itself in bargaining to reduce the incurred expenses.

Regarding the ownership of the company's interests, it is imperative to ascertain that the corporation holds $88.9 \%$ of its interest in the core zone.72.2 percent of the ownership interest of the corporation is held at Buffer Zone which is found at Ekati Diamond mines. Diavik Diamond mine hosts 40 percent of the ownership interest of the Dominion Diamond Corporation. The company is known to have a remarkable collection of mining assets and employees who are experienced and talented. Research studies have evidenced that the diamond market varies from the market of other precious metals. Ideally, this is because of the complexities that underlie the trading of diamond. However, the researchers further postulate that the increase in the demand for diamond in the United States and other countries may result in the deficit of diamond in the future market. Dominion Diamond corporation possess a strong balance sheet since its current assets amount to $\$ 842$ million and the current liabilities amount to $\$ 213$ million.

The working capital value of the company is stated as $\$ 629$ million. Regarding the current market capitalization, it is imperative to ascertain that the working capital of the corporation represents 43 percent of the current market capitalization. Research studies have evidenced that the Diamond Dominion Corporation has remarkable mining assets and a highly talented workforce. In the year 2012, the revenues of the company were stated as $\$ 702$ million [7].

The researchers further postulated that this was an increase of 12.5 percent from the previous year. In the same year, the operating profit of the corporation was stated as $\$ 56.5$ million. However, this was a decrease of 17.3 percent with the profitability that was made by the corporation in the previous years. In the year 2012, the net profit of the corporation was found to be $\$ 25.5$ million. This was a decrease of 38.7 percent as compared to the one of the previous years.

\section{Financial Summary}

Table 1: The Financial Summary of the Dominion Diamond Corporation Consolidated Performance Review (Ekati mine 100\% basis and Diavik mine $40 \%$ basis)

\begin{tabular}{|c|c|c|c|c|c|c|c|c|c|c|c|c|}
\hline \multirow[t]{2}{*}{ (in millions of US dollars, except where otherwise noted) } & \multicolumn{6}{|c|}{ Three months ended July 31} & \multicolumn{6}{|c|}{ Six months ended July 31} \\
\hline & & 2017 & & & 2016 & & & 2017 & & & 2016 & \\
\hline Sales & $\$$ & 239.8 & & $\$$ & 160.0 & & $\$$ & 450.8 & & $\$$ & 338.2 & \\
\hline Carats sold (000s) & & 3,643 & & & 1,341 & & & 5,976 & & & 3,940 & \\
\hline Average price per carat sold (\$/carat) & $\$$ & 66 & & $\$$ & 119 & & $\$$ & & & $\$$ & 86 & \\
\hline Cash cost of sales per carat sold ${ }^{(1)}(\$ /$ carat $)$ & $\$$ & 32 & & $\$$ & 74 & & & 37 & & $\$$ & 58 & \\
\hline Gross margin & $\$$ & 37.7 & & $\$$ & 0.9 & & & 68.4 & & & $(18.0)$ & \\
\hline Gross margin (\%) & & 16 & $\%$ & & 1 & $\%$ & & 15 & $\%$ & & $(5 \%)$ & \\
\hline Selling, general and administrative expenses & $\$$ & 7.4 & & $\$$ & 9.2 & & $\$$ & 15.6 & & $\$$ & 17.2 & \\
\hline Mine standby costs & $\$$ & - & & $\$$ & 22.0 & & $\$$ & & & $\$$ & 22.0 & \\
\hline Transaction costs & $\$$ & 11.2 & & $\$$ & - & & $\$$ & 11.2 & & $\$$ & - & \\
\hline Current and deferred income tax expense (recovery) & $\$$ & $(15.2)$ & & $\$$ & - & & $\$$ & 3.9 & & $\$$ & $(30.6)$ & \\
\hline Net (loss) income & $\$$ & 31.1 & & $\$$ & $(37.9)$ & & $\$$ & 23.2 & & $\$$ & $(43.2)$ & \\
\hline Adjusted EBITDA & $\$$ & 115.2 & & $\$$ & 38.6 & & $\$$ & 212.2 & & $\$$ & 92.9 & \\
\hline Adjusted EBITDA margin ${ }^{(1)}(\%)$ & & 48 & $\%$ & & 24 & $\%$ & & 47 & $\%$ & & 27 & $\%$ \\
\hline Depreciation and amortization & $\$$ & 85.1 & & $\$$ & 62.6 & & $\$$ & 160.9 & & $\$$ & 124.1 & \\
\hline Earnings (loss) per share attributable to shareholders (\$/share) & $\$$ & 0.39 & & $\$$ & $(0.39)$ & & $\$$ & 0.29 & & $\$$ & $(0.40)$ & \\
\hline $\begin{array}{l}\text { Cash from operating activities before changes in non-cash operating } \\
\text { working capital (1) }\end{array}$ & $\$$ & 63.9 & & $\$$ & 23.9 & & $\$$ & 137.4 & & $\$$ & 35.1 & \\
\hline Free cash flow & $\$$ & 42.8 & & $\$$ & $(20.9)$ & & & 27.3 & & $\$$ & $(110.9)$ & \\
\hline
\end{tabular}




\section{The Role of Internal Auditing in Preserving the Tangible Assets of Dominion Diamond Corporation}

Internal auditing plays a significant role in preserving and keeping the tangible assets of Dominion Diamond Corporation. As stated earlier, the company specializes in the distributing of Diamond in the international market. According to the auditing standards, the internal auditors of the corporation are tasked with the responsibility of auditing the management schedules in line with the accepted auditing standards. The standards require that the internal auditors should comply with the ethical standards and guidelines in carrying out the internal auditing.

The internal auditing of the Dominion Diamond Corporation entails the performing of procedures to gather solid evidence on the disclosures and the amount in the schedules of three corporations. However, the selected procedures are dependent upon the judgment of the internal auditors of the corporation. The judgments are also based on the risk evaluations made by the internal auditors. In incepting the risk assessments of Dominion Diamond Corporation, the internal auditors consider the internal control which is related to the schedules of the corporation to prepare and design the audit procedures that are effective in the prevalent circumstances.

The internal auditing of the Dominion Diamond Corporation also entails the assessing of the effectiveness of the accounting procedures and policies. One of the roles played by the internal auditors in protecting and preserving the tangible assets of the Dominion Diamond Corporation is the evaluation of compliance to ascertain whether the corporation adheres to the guidelines, the regulation laws and the code of practice. Through the periodical internal auditing compliance and review, internal auditing helps the corporations to identify and ascertain whether the tangible assets of the corporation are maintained in the proper condition.

The internal auditors of Dominion Diamond Corporation work by monitoring the internal controls of the organization. Before delivering a report on the efficiency of the management policies incepted in an organization, the internal auditors of the Dominion Diamond
Corporation evaluate and understand the risk management philosophy of the corporation. Given the fact that the internal auditors of Dominion Diamond Corporation carry out the evaluation of the operational performance of the Dominion Diamond Corporation, they review the operations of both the middle and low-level managers [8]. Such an initiative aids in accounting for all the tangible assets of the corporations, their usage and how they are utilized in the organization.

\section{The Bank of Montreal}

It is vital to examine the Bank of Montreal of Canada and its tangible asserts before carrying out an analysis on the importance of internal auditing on the preservation and protection of the tangible assets. The Bank of Montreal was incepted in the year 1817.During its inception, the bank functioned as the Central Bank of Canada. Regarding assets, the bank is ranked as the fourth largest bank in Canada. In North America, the corporation is ranked as the eight largest banks regarding assets. The corporation provides services in three distinct sections.

These areas include investment banking, management of wealth and commercial and personal banking. It is considered a public corporation that carries trading activities on the New York Stock Exchange and Toronto Stock exchange. In the year 2017, the revenues of the Bank of Montreal were stated as $\$ 22.2$ billion. The assets of the company mounted to $\$ 709.6$. The profit of the corporation was stated as $\$ 5.3$ billion. The corporation employs more than 45,200 employees. The banking products and services of the bank of Montreal include investment and finance advice services, creditor insurance products, savings and checking accounts, savings and checking accounts and the mortgages.

The commercial services and banking products of the organization include specialized banking programs from small business entities, the banking programs for commercial banking customers, the cash management solutions, the commercial credit cards, foreign exchange, commercial mortgages and the business loans. The Bank of Montreal has been ranked among the best performing banks in Canada. The bank also deals with the aspect of equity and research, 
debt underwriting, lending of corporations, financing of projects, giving of advice regarding the terms of merging and acquisitions, managing of the treasury, securitization, offering of trading services to the companies and the government clients. The Bank of Montreal also deals with the offering of trade financing and online investment. Additionally, the corporation provides tax planning and estate services to its investors and clients.

The corporation deals have 15,000 branches in both the United States and Canada. The tangible assets of the Bank of Montreal are used to refer to the inventories of the bank, the stock holdings, the accounts receivables, the buildings and the cash. The total assets of the company in January 2018 were found to be $\$ 585,654$ million. The growth in the total assets of the corporation in January was found to be 4.20 percent. The Bank of Montreal is endowed with attractive financial resources. This postulation can be evidenced by the tier capital ratio of the corporation which was found to be 12.3 percent in the year 2015.The standard equity ratio of the company was found to be 10.7 percent.
One of the factors that support the strong financial position of the organization is the high credit ratings which are possessed by the corporation [9]. The high credit ratings and the strong capital position of the corporation have enabled the company to capital markets even during the situations of volatile marketing conditions. Since the corporates adopt the use of the universal banking model, it gets an opportunity of diversifying and tapping into new markets.

The model also enables the organization to yield high benefits from the cross-selling opportunities. Since the corporation has a strong financial position in North America, it has benefited in gaining the economies of scale. As stated earlier, the business of the corporation is diversified. For example, the corporation obtains its revenues from various business segments such as the wealth management, the capital markets, the commercial banking and personal services and the corporate services. In the year 2015, the commercial banking and personal services accounted for 32.4 percent of the total amount of revenues of the corporation.

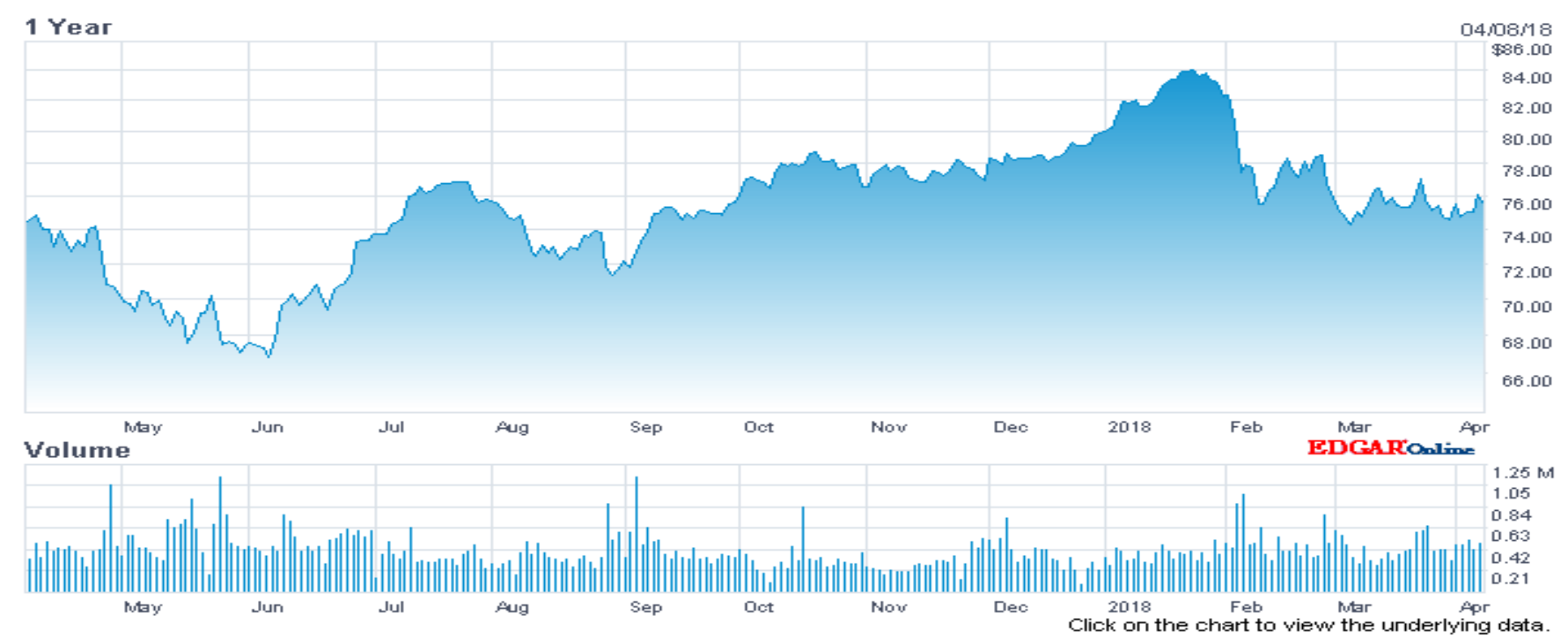

Figure 1: Showing the Stock of the Bank of Montreal

The Role of Internal Auditing in Protecting and Preserving the Tangible Assets of the Bank of Montreal

Internal auditing plays a significant role in preserving the tangible assets of banks. The bank of Montreal of Canada is among the corporations that have benefited in preserving their tangible assets from the embracement of internal auditing. As explained earlier, internal auditing deals with evaluating the aspect of compliance in the organizations. Internal auditing works towards ensuring that the assets of a corporation are used in the most effective way. The Bank of Montreal has benefited in embracing the use of internal auditing in its operations. One of the benefits that the corporation has attained from the embracement of internal auditing is that its resources are efficiently utilized. Through internal auditing, the Bank of Montreal has 
obtained an opportunity to monitor its operations to ensure that embraces the use of effective policies and procedures in carrying out its operations and activities. Regarding the internal auditors of the Bank of Montreal, it is imperative to ascertain that the internal auditors of the bank are required to have the effective potential regarding the regular reviews and regulatory interests. Internal auditing helps in strengthening the regulatory capital of the bank of Montreal. Bank corporations are subjected to the global regulatory framework [10].

The framework consists of the measures that are undertaken to help in the strengthening of the capital and the liquidity of the corporation. The internal auditors of the company review the management processes embraced by the bank in carrying out its operations and activities. The internal auditors also evaluate the internal reporting and regulation of the embraced by the Bank of Montreal. The internal auditors carry out regular evaluation of the appropriateness of the processes [11].

The internal auditors work towards ascertaining whether the reports postulated by the employees are timely, accurate and reliable. The corporation is supposed to present the standardized reports which are embraced in recording the ratios, requirements and capital resources of a company. The compliance function given to the internal auditors helps in preserving and protecting the tangible assets of a corporation. The internal auditors carry out a periodic review and evaluation of the activities of the organization to ascertain whether they comply with the set laws, regulations, and standards.

The evaluation of the finance section also explores on the functions and roles of the internal auditors in protecting the tangible assets of the bank of Montreal of Canada. Banks are required to comply with the aspects of integrity and accuracy when incepting their financial statements. The major activities of finance such as calculation of the profits and losses of the corporation, determination of the reserves have a significant effect on the resources of the corporation [12]. The subjection of the losses, reserves and profits of the company for periodical evaluation and assessment helps in determining whether the transactions made the particular employees of the corporation are accurate. Through internal auditing, the performance of the corporation is ascertained to determine the extent to which the organization meets the set objectives and goals. For this reason, the aspect of internal auditing in the corporation is crucial as it helps in preserving the tangible assets of the company to ensure that the accounting transactions are made accurately without an act of misrepresentation or any fraudulent activities.

Comparison of the Importance of Internal Auditing in Preserving and Protecting the Tangible Assets of the Bank of Montreal and the Dominion Diamond Corporation of Canada

An explicit evaluation of the aspect of internal auditing in the Dominion Diamond Corporation and the bank of Montreal indicates that there exist differences and similarities regarding the use of internal auditing in protecting and preserving the tangible assets of the corporations. It is therefore imperative to evaluate the similarities and differences that underlie the use of internal auditing in the two corporations.

\section{The Similarities}

One of the similarities underlying the importance of internal auditing in both the bank of Montreal and the Dominion Diamond Corporation is that in both cases internal auditing help on curtailing the issues of fraud and misrepresentation on the use of the tangible assets. As stated earlier, the Dominion Diamond organization embraces the use of internal to curb fraudulent activities regarding the use of the tangible assets [13].

In most cases, organizations lose high values of money due to theft in the corporations. Some of the fraudulent activities that might be available or prevalent in the corporations under evaluation include tampering of the checks, improper transactions entailing the payrolls, misuse of the credits of the corporations and cash theft. Carrying of internal auditing in both the bank of Montreal and the Diamond Dominion Corporation helps in combating such fraudulent activities. The internal auditing program in both cases aids in monitoring the 
staff individuals and their behaviors in the organization. The internal auditing of the financial transactions in the corporations helps in curbing the staff members and the stakeholders from misusing the tangible assets of the two corporations. From the evaluation of the Dominion Diamond Corporation of Canada, it is imperative to ascertain that the corporation has maintained both its liquidity and cash flows. Additionally, it was expounded earlier that Dominion Diamond Corporation possesses a strong balance sheet since its current assets amount to $\$ 842$ million and the current liabilities amount to $\$ 213$ million.

The working capital value of the company is stated as $\$ 629$ million. Regarding the current market capitalization, it is imperative to ascertain that the working capital of the corporation represents 43 percent of the current market capitalization. The stringent measures of internal auditing ensure that the corporation makes appropriate financial transactions and that the figures given in the corporation are of fair value [14].

In both of the companies under analysis, it is evident to ascertain that internal auditing helps in monitoring and incepting internal controls in the corporations. Through the examining of procedures and policies embraced in the corporations, the internal auditing help in minimizing the loss of the tangible assets. The internal auditors of both corporations help in incepting the control policies and procedures for the organization. For instance, the internal auditors of the bank of Montreal are given the authority to ascertain the amount of credit that should be given to the customers and the type of customers who should be given credit [15].

For this reason, the internal auditors of both corporations help in preserving and protecting the tangible assets of the corporations. The internal auditors help on designing the credit policies and procedures for the two corporations to avoid the problems and issues of bad debts especially for the customers who do not possess creditworthiness._In both cases, the internal auditors carry out operation auditing. Operational auditing helps in examining and evaluating the practices of a particular corporation to ascertain the extent to which an organization complies with the set procedures, guidelines and standards.
The embracement of ineffective procedures and operations in a corporation can result in increased overheads and decreased profitability. Carrying out of operational audit aids in detecting the inefficiencies and ensuring that they are collected before they result in a decline in the profitability of the corporation. In the Dominion Diamond Corporation, the internal auditors examine the operations of the organization to detect inefficiencies in the embraced practices.

Similarly, the internal auditors of the Bank of Montreal carry out operational auditing to carry out the detection of the inefficiencies. Operational auditing helps the corporations to ascertain the areas where the employees and the staff members do not comply with the set rules and standards. Such an initiative helps in helping the organization to evade the fines that might be imposed when an organization fails to comply with the set regulations and standards. The provision of objective insight is another importance that is similar in both corporations in preserving the tangible assets of the Bank of Montreal and the Dominion Diamond Company of Canada [16].

In the two organizations, the internal audit function help in adding value to the corporations. Ideally, this is because the internal auditors in the organizations help in motivating the other employees to value the aspect of internal auditing and therefore, they work towards enhancing organizational performance. Both the employees of the Bank of Montreal and those of the Dominion Diamond Corporation of Canada value the aspect of internal auditing and therefore they work towards embracing the practices and policies that are suggested by the internal auditors.

\section{The Differences}

Despite the similarities identified on the role of internal auditing in preserving and protecting the tangible assets of the Bank of Montreal and Dominion Diamond Corporation, it is imperative to ascertain that there are variations that exist in the usage of internal auditing in protecting the tangible assets an organization [17]. One of the noted variations is that the internal auditors of the bank of Montreal emphasized the cash reserves, the financial assets of the organizations such as the cash flows, the 
balance sheet, the profit and loss account, the income statements, and the employees of the corporation. On the contrary, the internal auditors of the Dominion Diamond Corporation focus on the operations and the activities of the organization, the financial aspects and the cash reserves. However, it is imperative to ascertain that the Dominion Diamond organization focuses on the mines and how the individuals who are employed at the mines execute their activities.

The internal auditors of the Bank of Montreal emphasize on how the activities carried out in the bank are executed and whether they are performed effectively. Another observed variation is that the internal auditors of the bank of Montreal emphasize on the aspect of profit and loss when auditing the books of the corporation. On the contrary, the Dominion Diamond organization puts focus on the balance sheets of the corporation to ascertain the appropriateness of the entry of the transactions.

\section{Reaction}

I presume that internal auditing plays a significant role in the protection of tangible assets of the organizations. It is through internal auditing that the organizations can ascertain their compliance to set standards and regulations. Ideally, the internal auditors carry out an analysis on the extent to which the corporations adhere to the incepted standards and regulations. From the evaluation of the bank of Montreal and the Dominion Diamond Corporation, it is imperative to depict that internal auditing helps the corporations to protect their tangible assets.

Through internal auditing, the auditors can identify the cases of fraud that may result in the destruction or theft of the tangible assets. For instance, the bank of Montreal has yielded many benefits from the embracement of internal auditing since the auditors carry an evaluation of the financial transactions to ascertain whether the transactions are executed in an effective way. The practice of internal auditing creates an opportunity for the auditors to offer recommendations on the policies and procedures that should be adopted by the corporations. For instance, if the internal auditors ascertain that there are cases of fraud entailing the transactions, they can advise the organizations on the best practices they should adopt to curtail the occurrence of fraudulent activities. I portend that the use of internal auditing in both the bank of Montreal and the Dominion Diamond Corporation consists of various similarities. One of the similar aspects is that the aspect of internal auditing in both organizations helps in curbing the cases of fraudulent practices regarding the protection of tangible assets. Internal auditing is of a high value in organizations and therefore organizations should work towards incepting the aspect of internal auditing.

\section{Opinion}

From the foregoing discussion, it can be presumed that internal auditing plays a significant role in protecting the tangible assets of a given corporation. Both the Bank of Montreal and the Dominion Diamond Corporation embrace the use of internal auditing in protecting their assets. Through internal auditing, the organization can ascertain the cases of fraud and the sources of fraudulent activities in the organizations. The internal auditors play a role of incepting the mitigation approaches to aid in curbing the cases of fraud in the respective companies. I therefore recommend the organization to continue embracing the aspect of internal auditing since it is a valuable practice in the organization.

\section{Conclusion}

In the light of the above discussion, it is vital to point out that the practice of internal auditing plays a significant role in the protection and preservation of the tangible assets of the organization. Through the analysis of the bank of Montreal and the Dominion Diamond Corporation, it is imperative to depict that internal auditing plays a significant role since it aids the organization to develop a strong compliance towards the making of entries, especially when making transactions.

Such an approach gives an opportunity for the corporations to determine the areas where the transactions are made inappropriately. As explained earlier, the Dominion Diamond organization embraces the use of internal to curb fraudulent activities regarding the use of the tangible assets. In most cases, organizations lose high values of money due to theft in the corporations. 
Some of the fraudulent activities that might be available or prevalent in the corporations under evaluation include tampering of the checks, improper transactions entailing the payrolls, misuse of the credits of the corporations and cash theft [18]. Therefore, adopting the practice of internal auditing helps in curbing the fraudulent activities a fact that works towards ensuring the security of the tangible assets.

The aspect of operational auditing embraced by the internal auditors also explores the importance of internal auditing in protecting the tangible assets of the company. As pointed out earlier, operational auditing aids in the assessing and examining the practices of a particular corporation to ascertain the extent to which an organization complies with the set procedures, guidelines, and standards. The adoption of ineffective procedures and operations in a corporation can result in increased overheads and decreased profitability.

Carrying out of operational audit aids in detecting the inefficiencies and ensuring that they are collected before they result in the decrease of the profits made by the corporations. Another importance of internal auditing in protecting the tangible assets of the company. Internal auditing also aids in the provision of important insights to an organization. Some of the aspects that the internal auditors help the corporations to deal with include the policies and procedures of the company, the culture of the corporation, the aspect of regulatory compliance and the risk mitigation approaches [19].

Internal auditing is also considered a primary factor in ensuring the formation of successful relationships with the clients. Regarding the comparison of the essence of tangible assets in protecting the tangible assets of the Bank of Montreal and the Dominion Diamond Company, it is vital to point out that there exist some differences and similarities on how the practice of internal auditing is adopted in preserving the tangible assets of the two corporations under evaluation. One of the noted similarities is that both of the corporations embrace the use of internal auditing in detecting the inefficiencies that may occur when making financial entries and transactions [20].
The variation regarding the use of internal auditing in the two corporations.

\section{References}

1. Bank of Montreal SWOT Analysis (2017)" Bank of Montreal SWOT Analysis (August 18): 1-7. Business Source Complete, EBSCOhost (accessed April 7, 2018)

2. "Bank of Montreal (2017)" Bank of Montreal Market line Company Profile, 31:1-33.

EBSCOhost, search.ebscohost.com/login.aspx?direct=tr ue\&db=bth\&AN=126343989\&site=ehostlive.

3. "Bank of Montreal SWOT Analysis (2015)"
1-7. Business
Source
Complete,

EBSCOhost (accessed April 7, 2018).

4. "Company Spotlight: Bank of Montreal (2012)" Market watch: Financial Services 12(6): 35-40. Business Source Complete, EBSCOhost (accessed April 7, 2018).

5. "Harry Winston Diamond Corporation (2013)" 1-16. Business Source Complete, EBSCOhost (accessed April 7, 2018).

6. "Bank of Montreal (2017)" 1-24. Business Source Complete, EBSCOhost (accessed April 7, 2018).

7. "Company Spotlight: Bank of Montreal (2012) "Market watch: Financial Services 12, no. 6: 35-40. Business Source Complete, EBSCOhost (accessed April 7, 2018).

8. "Data monitor: Bank of Montreal (2011)" 1-8. Business Source Complete, EBSCOhost (accessed April 7, 2018).

9. International Monetary, Fund (2014) Canada: Financial Sector Assessment Program Stress Testing, Technical Note. Washington, District of Columbia: International Monetary Fund, 2014. EBook Collection (EBSCOhost), EBSCOhost (accessed April 7, 2018).

10. "Retail Savings (2017) Investments Industry Profile: Canada." Retail Savings \& Investments Industry Profile: Canada (2017): 1-40. Business Source Complete, EBSCOhost (accessed April 7, 2018).

11. Ridley Jeffrey (2008) Cutting Edge Internal Auditing. Chichester, England: 
Wiley, eBook Collection (EBSC O host), EBSC O host (accessed April 7, 2018).

12. Mussio, Laurence BA (2016) Vision Greater Than Themselves: The Making of the Bank of Montreal, 1817-2017. Montreal: MQUP,. EBook Collection (EBSCOhost), EBSCOhost (accessed April 7, 2018).

13. Mussio Laurence B (2017) "FIRST BANK." Canada's History 97(5): 4246. Academic Search Premier, EBSCOhost (accessed April 7, 2018).

14. "Retail Savings (2017) Investments Industry Profile: Canada." Retail
Savings \& Investments Industry Profile: Canada: 1-40. Business Source Complete, EBSCOhost (accessed April 7, 2018).

15. Siti Rosmaini binit Mohd Hanafi, Kasim Mohd, Ariff bin (2015) Internal Auditing and Enterprise Risk Management (ERM): A Research Approach on the Evolution, Roles of Internal Auditors, Implementation, Challenges and the Impact of the ERM on Organisational Performance. Hauppauge, New York: Nova Science Publishers, Inc, 2015. EBook Collection (EBSCOhost), EBSCOhost (accessed April 7, 2018) 


\section{Appendix}

\section{Figure Showing the Value of Stock of the Bank of Montreal}

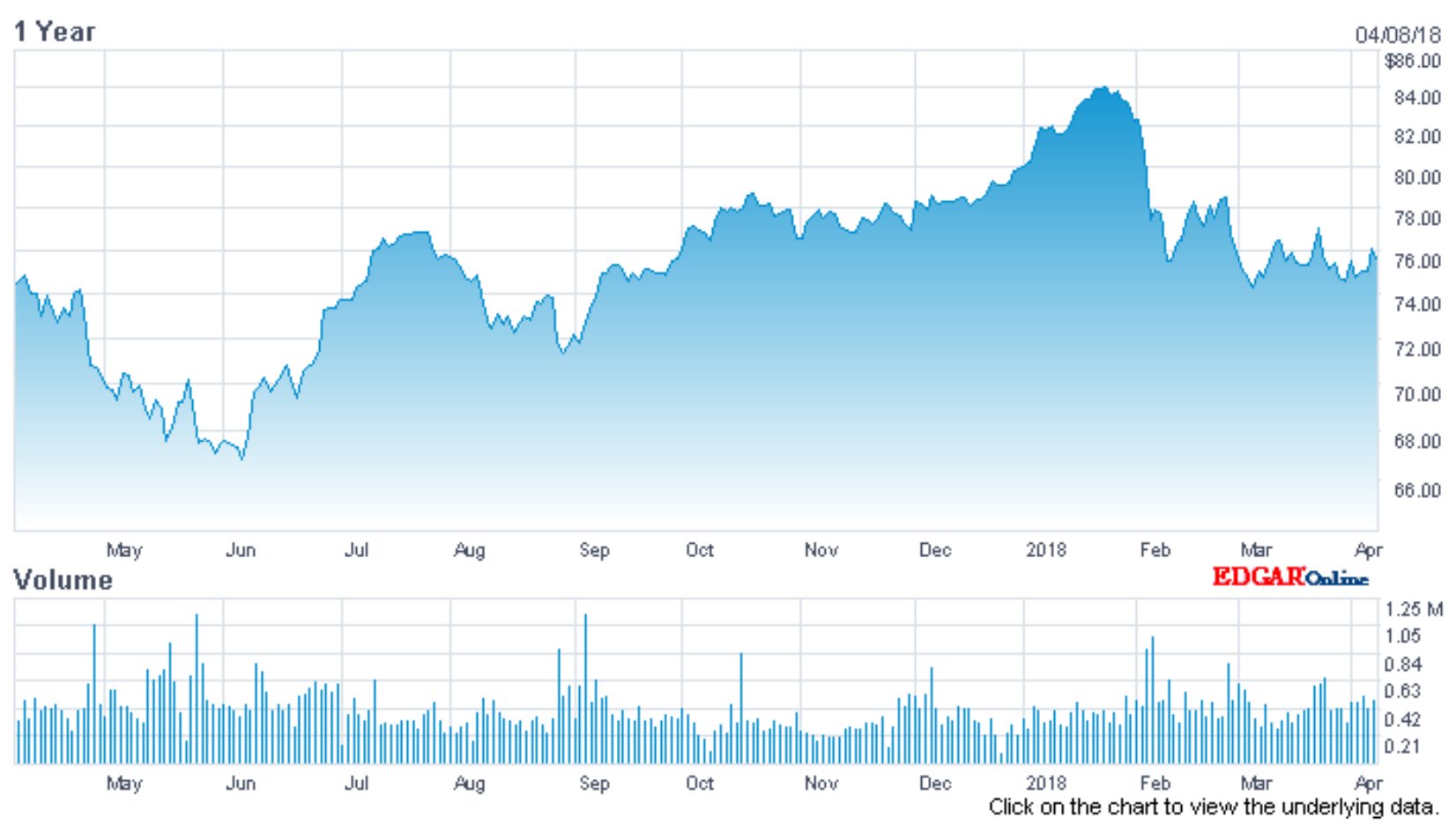

Financial Summary of the Dominion Diamond Corporation

Consolidated Performance Review (Ekati mine 100\% basis and Diavik mine $40 \%$ basis)

Financial Summary

(in millions of US dollars, except where otherwise noted)

Three months ended July Six months ended July 31

\begin{tabular}{|c|c|c|c|c|c|c|c|c|}
\hline & 2017 & & 2016 & & 2017 & & 2016 & \\
\hline Sales & $\$ 239.8$ & & $\$ 160.0$ & & $\$ 450.8$ & & $\$ 338.2$ & \\
\hline Carats sold (000s) & 3,643 & & 1,341 & & 5,976 & & 3,940 & \\
\hline Average price per carat sold (\$/carat) & $\$ 66$ & & $\$ 119$ & & $\$ 75$ & & $\$ 86$ & \\
\hline Cash cost of sales per carat sold ${ }^{(1)}$ (\$/carat) & $\$ 32$ & & $\$ 74$ & & $\$ 37$ & & $\$ 58$ & \\
\hline Gross margin & $\$ 37.7$ & & $\$ 0.9$ & & $\$ 68.4$ & & $\$(18.0)$ & \\
\hline Gross margin (\%) & 16 & $\%$ & 1 & $\%$ & 15 & $\%$ & $(5 \%)$ & \\
\hline Selling, general and administrative expenses & $\$ 7.4$ & & $\$ 9.2$ & & $\$ 15.6$ & & $\$ 17.2$ & \\
\hline Mine standby costs & $\$-$ & & $\$ 22.0$ & & $\$-$ & & $\$ 22.0$ & \\
\hline Transaction costs & $\$ 11.2$ & & $\$-$ & & $\$ 11.2$ & & $\$-$ & \\
\hline Current and deferred income tax expense (recovery) & $\$(15.2)$ & & $\$-$ & & $\$ 3.9$ & & $\$(30.6)$ & \\
\hline Net (loss) income & $\$ 31.1$ & & $\$(37.9)$ & & $\$ 23.2$ & & $\$(43.2)$ & \\
\hline Adjusted EBITDA & $\$ 115.2$ & & $\$ 38.6$ & & $\$ 212.2$ & & $\$ 92.9$ & \\
\hline Adjusted EBITDA margin ${ }^{(1)}(\%)$ & 48 & $\%$ & 24 & $\%$ & 47 & $\%$ & 27 & $\%$ \\
\hline Depreciation and amortization & $\$ 85.1$ & & $\$ 62.6$ & & $\$ 160.9$ & & $\$ 124.1$ & \\
\hline Earnings (loss) per share attributable to shareholders ( $\$ /$ share) & $\$ 0.39$ & & $\$(0.39)$ & & $\$ 0.29$ & & $\$(0.40)$ & \\
\hline $\begin{array}{l}\text { Cash from operating activities before changes in non-cash } \\
\text { operating working capital }\end{array}$ & $\$ 63.9$ & & $\$ 23.9$ & & $\$ 137.4$ & & $\$ 35.1$ & \\
\hline Free cash flow & $\$ 42.8$ & & $\$(20.9)$ & & $\$ 27.3$ & & $\$(110.9)$ & \\
\hline
\end{tabular}

